therc is liardly any need for anxstheties. The paticnt is laid on her back, if the uterus ean be easily drawn down; if not, she must be placel either on the riglit or the left side, according to the lacerations. Spiegelberg nses metal wirc. The wire is generally removed on the tenth day, and the patient is allowed to leave her bed on the eightll day. Little must be done in the way of treatment, except keeping her quiet. Ont of the anthor's ten cesses, the wound liealed by first intention in six; in three, by second intention; and in one case, one side did not heal at all._British Med. Journal, July 12, 1879.

\title{
Treatment of Uterine Fibroids by Ergot.
}

Dr. G. Ernest Herman, Assistant Obstetric Physicim to the London Hospital, in a paper read before the Hunterian Society (Med. Times and Gaz., Aug. 23,1879 ), considers this subject and offers the three following propositions as being warranted by the facts before the profession.

1. That ergot will often produce the dimimution in size, and somctimes cren complete absorption, of fibroid tumou's of the uterus, and will, in the majority of cases relieve their synptoms.

2. That these effects will often follow the administration of the drug by the month, but will more certainly be produced by its hypodermic injection in the neighbourhood of the tumour.

3. That in all cases in which treatment is required, except those in which surgical interference is needed to avert inmerliate danger to life, this treatment should be tried before resorting to operative measures.

\section{Oöphorectomy in a case of Congenital Vaginal Defect.}

At the eightl Congress of German Surgeons, held in Berlin last April, Prof. von LAxGExBeck (Wiener Medizin. Wochenschrift) exhibited a woman, aget 23, on whom he had performed Battey's operation. She lutd been malried three ycurs. The catmmenia commenced at the age of $14 ;$ and, as was afterwirds discovered, the discharge took place per urethram, the vagina being entirely alsent. The discharge was scmity, but was always attended with severe pain. Coitus was also effected by the urethra. As the menstrual troubles had lately inereased to such an extent as to produce epileptiform attacks, Dr. von Langenbeck decicled on extirpating the right ovary by Battey's metliod. He had ascertaincd by careful examination that the left oviry was wanting, and that the uterns was rudinentary. An incision about two inches long was mude in the flank; the pedicle of the ovary was tied with catgut, and scwn to the abdominal womnl. 'The process of healing was uninterrupted; the ligatired remains of the pedicle fell off on the fourteentl day. Menstruation took place on the fifth day after the operation, although one ovary was removed, and the absence of the other had been ascertained both before and during the operation. Dr. von Langeuberk expressed his sutisfaction with the result obtained, and recomnended the proceeding for adoption in similar cases._-British Med. Journal, July 12, 1879.

\section{The Treatment of the Pedicle in Orarivtomy.}

Professor Splegklberg reports (Berliner Klinische Wochenschrift, May 5, 1879) the result of thirty-five lospital cases of ovariotomy performed according to Lister's antiseptic methol in its fillest extent, with special referenee to the question as to what treatment of the pediele is most suitably combined with the antiseptic method. Of these thirty-five eases, only 5, or 14 per cent., dierl; whereas in forty-five operations previously performed by him witlout the carbolic spray, twenty paticnts, or 45 per' eent., died. 'The present series of cases Spiegelberg brings forward to show that it is possible, in conjunction with the antiseptic 
method, to adopt the extra-peritoneal method of treating the pedicle with at least as great sureess as if it were ligatured and returnel. Of the two methods he is inclined to prefer the treatment by clamp. Of nineteen eases treated with the elamp, eighteen recovered; while, of sixteen in whom the pediele was ligatured and clropped, four died. In the latter, lowever, were included the most difficult eases. The author admits some degree of force in certain oljections to the use of the clamp, namely, the frefuent ocenrrence of suppuration in the lower angle of the wound, the slower healing of the wound, and the formation of a broader and less firm cieatrix at its lower angle. Ile docs not eonsider, however, that, with due eare, there is any danger of the pediele slipping back into the abdominal cavity, or of septic material finding aceess to the raw end of the perlicle; and he has not found in his experience any deleterions after-effects, either with regard to menstruation or pregnancy, from the arlhesion of the pedicle to the alolominal wall. His great objection to the intri-peritoneal mode of treating the pedicle is that pelvic suppuration later on, set up by the presenee of the ligatures, is by no means very rare in patients thus treated. Ile therefore concludes that the future of patients with a elamped pedicle is a safer one than that of those in whom the pedicle las been ligatured and returned.-Olstet. Journ. of Gt. Britain, Aug. 1879.

In an article in the Finskia Läkarasällskapets Handlingar, Band xix., Dr. F. SALTZMAN relates the histories of seven cases of oviriotomy recently performed by him, and makes some remarks on (nestions bearing on the operation. In six of the cases, as in all the similar operations previously deseribed by him, he used the aetual enutery in the treatment of the perlicle. 'The most important objeetion against this method, namely, that it does not affiorl a sure protection against seeoudary hemorrhage, mar, in his opinion, be olviaterl by taking the precaution to tie ench ressel in the pediele with catgut. If it loc desired to agaiu ligatile the pedicle, he regurds eatgut as the most suitable material. From lis own observations and from those of others, the author has come to the conclusion that the fear lest the catgut ligature shoule fail to afford seeurity arainst secoullary hemorrhage, in eonsequence of its realy absorption, has been exaggerated. The author points out some inconveniences of the extraperitoneal method of mangement of the pedicle, anong whiel he especially directs attention to the ocenrence of tetanus in some of the eases treated in this way, and sums up by declaring his preference for the intraperitoneal methorl. This method is applicable in all cases, and the only important point is the ehoice between the ligature and the actual cautery. He decidedly prefers the cautery when one has to deal with a thick pedicle, espeeially when no large arteries ean be detected in it. T'le ligature is indicated, in the first place, when the pedicle is eomparatively thin, and contains arteries of large ealibre; and it is absolutely required in cases where the pedicle is so short that the eautery-elimp eannot be applied, and where the tumour eannot be shelled out so as to form a pedicle. With regard to the use of the drainage-tube, especially in Douglis's pouel, Dr. Saltzman regards it as applicable only in some very rare exceptional eases. Of lis seren operations, two were followed by deatl. He gives reasons for the use of antiseptics in the operation._British Med. Journal, July 12, 1879, from Nortiskt Med. Arkiv, Bd. xi.

\section{MEDICAL JURISPRUDENCE AND TOXICOLOGY.}

\section{Antidotes for Strychnia.}

Dr. Husemand has confirmed (Arch. f. exp. Path., x. p. 101) the experiments of Amagat that in eases of poisoning by small doses of strychuia, the 